\title{
Phytochemical Screening of Tannins in Selected Indigenous Plants Species Used as Chewing Sticks in Ekiti State, Nigeria
}

\author{
Oluwafoise, B. G. \\ Biology Department, College of Education, Ikere-Ekiti \\ Adaramodu, A. A. \\ Chemistry Department, College of Education, Ikere-Ekiti
}

\begin{abstract}
Chewing sticks form an alternative to modern tooth pastes and brush and their use in brushing the teeth predates the later. The astringent and antimicrobial properties of tannins in chewing sticks give it one of its therapeutic values. This paper present a critical look at the analysis of tannins in selected indigenous plant species used as chewing sticks in Ekiti State, Nigeria. Forty eight (48) plant species belonging to 28 different families observed to be used for dental and oral health care in the study area were screened for the presence of tannins. Result of tannin phytochemical screening revealed that 34 (70.83\%) contained tannins, while the remaining 14 (29.17\%) do not contain tannin. In conclusion, the results showed that most of the Nigerian chewing sticks do contain tannins which have antibacterial activities which may contribute to the reported anticaries effect of chewing sticks. These sticks may be sources for new lead antibacterial agents for therapeutic or preventive applications. Based on the result obtained, it was recommended that users of chewing sticks should be sensitized on the type of chewing sticks that are of potential therapeutic benefit (anti-microbial) to the mouth health especially those containing tannins.
\end{abstract}

DOI: $10.7176 / \mathrm{JBAH} / 9-24-05$

Publication date: December $31^{\text {st }} 2019$

\section{Introduction}

The role of plants in maintaining effective oral hygiene cannot be undermined. A number of plant species are used as chewing sticks, most of which have substances in them that can keep the buccal cavity healthy. The actions of certain bacteria in the mouth are known to cause several oral infections. The most common oral infections are periodontal diseases that are mainly caused by bacterial plaque accumulation around the teeth as a result of poor oral hygiene (Kemboi, 2016). This infection affects all humans without regard for race or gender or better still the origin of a person or his/her nationality. For example, The World Health Organization (WHO) ranks oral disease among the top five causes of health burden in the world (WHO, 2004).

Some plants possess antimicrobial activity against oral microbial flora. This indicates that some chewing sticks (plant), in addition to providing mechanical stimulation to the gums and teeth also destroy microbes present in the mouth (Homer et al., 1990). Dental care needs of the majority of Nigerians remains largely unmet because there are a few professionals offering care, as a result services are often too costly, scarce or totally absent especially in rural areas (Kayode, 2005). Chewing sticks are said to be twigs or roots of certain plants that are chewed until one end is frayed and brush-like. This end can be used to brush against the teeth (Price and Butter, 2017).

Chewing sticks constitute an important non-wood forest product (NWFP) in Ekiti State, Nigeria where tooth cleaning with botanicals has formed part of the cultural norms). They are commonly used as close substitutes or alternatives to modern tooth pastes and brush by people in many developing countries like Nigeria. In Nigeria, the use of chewing stick is peculiar to the countryside; however, semi-urban and urban residents also use chewing sticks. The choice of stick depends on the known or perceived cleansing potentials, taste (peppery or bitter), therapeutic values, simplicity in being chewed into brush, and the ability to froth (Akande and Ajao, 2011). Isawunmi (1978) further asserted that in Nigeria, prior to civilization, cleaning of the teeth were initially done with chewing sticks before the prevalence of the use of modern tooth paste and brush. Previous studies by Isawemi (1978 a, b,c, and 1979) have revealed that the common chewing stick in Nigeria consist of 23 botanical species that belong to 14 species.

It has been reported that plants most commonly used as chewing sticks are those that have a high content of tannins (astringent and antibacterial) or other compounds that benefit the health of gums and teeth (Wolf and Rohan, 2009). Tannins (or tannoids) are a class of astringent poly phenolic biomolecules that bind to and precipitate proteins and various other organic compounds including ammonic acids and alkaloids (Akande and Hayashai, 2008). The tannin compound are widely distributed in many species of plants, where they play a role in protection from, predation (including as pesticides) and might help in regulating plant growth (Adekunle and Odunkoya, 2006).

The importance of chewing sticks in maintaining oral or buccal hygiene has been well reported. Adekunle and Odunkoya, 2006 reported the importance of chewing stick, particularly to the relatively low cases of dental 
caries and maintenance of strong teeth. In chewing sticks, tannin forms a coat over the enamel and thus protect against tooth decay (Gills, 1992). In most part of Africa, chewing sticks are often cut into pieces to make concoction thereby extracting tannins from the sticks for healing open wounds, stomach ache, diarrhea, gunn diseases and fever (Odukoyaet al, 2001). According to Sofowora (2008), secondary compounds in acacia contain tannins are important for a variety of functions, chief among these are anti-microbial, anti-cancer diveric, natriuretic, important nutraceutical, anti-digestive disorder, anti-oxidant, antiplasmodia.

The aim of this study therefore is to screen the selected indigenous plants used as chewing sticks in Ekiti State, Nigeria for the presence of tannins using different organic solvents - etanol, hexane and dichloromethane (DCM) and compare the potency of the various extractants for tannin.

\section{Materials and Method}

\section{Sample Preparation}

Samples of roots and stems of forty-eight different indigenous plants commonly used as chewing sticks were collected in Ekiti State between November and January period. This period of the year fall within the dry season month where adequate sunlight is present with little or no disturbance of rain. The samples were air-dried in a cool area twelve weeks after which dried samples were ground into powder. $300 \mathrm{~g}$ each of dried powder of the stem and root samples were extracted into $80 \%$ ethanol, Hexane and Dichloromethane respectively for two days at room temperature. The solutions are filtered. The solvent-containing extracts was then decanted and filtered in a 500 $\mathrm{mL}$ beaker through cotton wool to remove course particles and lastly through filter paper (Whatmann No.1) to obtain crude extract.

\section{Test for Tannins}

One milliliter of the filtrate was mixed with $3 \mathrm{~mL}$ of iron III chloride $\left(\mathrm{FeCl}_{3}\right), \mathrm{A}$ dark green color indicated a positive test for the tannins.

\section{Results and Discussion}

The results of phytochemical screening are presented in the table below of the various plant samples are presented in the table below.

\section{Table 1. Result of tannin screening}

\begin{tabular}{|c|c|c|c|c|c|c|c|}
\hline \multirow[t]{2}{*}{$\mathbf{S} / \mathbf{N}$} & \multirow[b]{2}{*}{ Botanical Name } & \multicolumn{3}{|c|}{ Stem Extract } & \multicolumn{3}{|c|}{ Root Extract } \\
\hline & & $\begin{array}{l}\text { Ethanol } \\
\text { Extract }\end{array}$ & $\begin{array}{l}\text { Hexane } \\
\text { Extract }\end{array}$ & $\begin{array}{l}\text { DCM } \\
\text { Extract }\end{array}$ & $\begin{array}{l}\text { Ethanol } \\
\text { Extract }\end{array}$ & $\begin{array}{l}\text { Hexane } \\
\text { Extract }\end{array}$ & $\begin{array}{l}\text { DCM } \\
\text { Extract }\end{array}$ \\
\hline 1 & Alchornea cordifolia & + & + & + & + & + & + \\
\hline 2 & Alchornea laxiflora & + & + & + & + & + & + \\
\hline 3 & Alstonia boonei & + & + & + & + & + & + \\
\hline 4 & Anacardium occidentale & + & + & + & + & + & + \\
\hline 5 & Anogeissus leiocarpus & + & + & + & + & + & + \\
\hline 6 & Azadirachta India & - & - & - & - & - & - \\
\hline 7 & Blighia sapida & + & + & + & + & + & + \\
\hline 8 & Bridelia ferruginea & + & + & + & + & + & + \\
\hline 9 & Bridelia micrantha & + & + & + & + & + & + \\
\hline 10 & Buchholzia coriacea & + & + & + & + & + & + \\
\hline 11 & Calliandra portoricensus & - & - & - & - & - & - \\
\hline 12 & Capsicum annuиm & - & - & - & - & - & - \\
\hline 13 & Carpotobia lutea & + & + & + & + & + & + \\
\hline 14 & Citrus aurantifollia & - & - & - & - & - & - \\
\hline 15 & Clerodondron buchholziii & + & + & + & + & + & + \\
\hline 16 & Combretum racemosum & - & - & - & - & - & - \\
\hline 17 & Croton zambesicus & - & - & - & - & - & - \\
\hline 18 & Cynometra vogellii & + & + & + & + & + & + \\
\hline 19 & Diospyros monbuttensis & + & + & + & + & + & + \\
\hline 20 & Duranta erecta & - & - & - & - & - & - \\
\hline 21 & Garcinia kola & + & + & + & + & + & + \\
\hline 22 & Garcinia mannii & - & - & - & - & - & - \\
\hline 23 & Gliricidia sepium & + & + & + & + & + & + \\
\hline 24 & Glyphaea brevis & + & + & + & + & + & + \\
\hline 25 & Hibsicusrosa-sinensis & + & + & + & + & + & + \\
\hline 26 & Harungana madagascariensis & + & + & + & + & + & + \\
\hline
\end{tabular}




\begin{tabular}{|l|l|c|c|c|c|c|c|}
\hline \multirow{2}{*}{ S/N } & \multirow{2}{*}{ Botanical Name } & \multicolumn{3}{|c|}{ Stem Extract } & \multicolumn{3}{c|}{ Root Extract } \\
\cline { 3 - 8 } & & $\begin{array}{l}\text { Ethanol } \\
\text { Extract }\end{array}$ & $\begin{array}{l}\text { Hexane } \\
\text { Extract }\end{array}$ & $\begin{array}{l}\text { DCM } \\
\text { Extract }\end{array}$ & $\begin{array}{l}\text { Ethanol } \\
\text { Extract }\end{array}$ & $\begin{array}{l}\text { Hexane } \\
\text { Extract }\end{array}$ & $\begin{array}{l}\text { DCM } \\
\text { Extract }\end{array}$ \\
\hline 27 & Jatropha curcas & + & + & + & + & + & + \\
\hline 28 & Jatropha gossypiifolia & - & - & - & - & - & - \\
\hline 29 & Jatropha multifida & + & + & + & + & + & + \\
\hline 30 & Mallotus oppositifolius & + & + & + & + & + & + \\
\hline 31 & Magnifera indica & + & + & + & + & + & + \\
\hline 32 & Masscularia acuminate & + & + & + & + & + & + \\
\hline 33 & Milletia thonningii & + & + & + & + & + & + \\
\hline 34 & Ocimum gratissimum & - & - & - & - & - & - \\
\hline 35 & Olaxsubscorpoidea & - & - & - & - & - & - \\
\hline 36 & Prerseagratissima & + & + & + & + & + & + \\
\hline 37 & Phaulopsis imbracata & + & + & + & + & + & + \\
\hline 38 & Psidium guajava & - & - & - & - & - & - \\
\hline 39 & Pycnanthus angolensis & + & + & + & + & + & + \\
\hline 40 & Sarcocephalusl atifolius & + & + & + & + & + & + \\
\hline 41 & Senna siamea & + & + & + & + & + & + \\
\hline 42 & Sida acute & + & + & + & + & + & + \\
\hline 43 & Sida corymbosa & + & + & + & + & + & + \\
\hline 44 & Terminalia schimperiana & + & + & + & + & + & + \\
\hline 45 & Theobroma cacao & + & + & + & + & + & + \\
\hline 46 & Trema orientals & - & - & - & - & - & - \\
\hline 47 & Vernonia amygdalina & + & + & + & + & + & + \\
\hline 48 & Zanthoxylum xanthoxyloides & - & - & - & - & - & - \\
\hline
\end{tabular}

Forty-eight (48) plant species belonging to 28 different families were observed to be in use for dental and oral health care in the study area. The various similarity measures related that similar plant species were used and most of these species were indigenous.

Result of phytochemical screening for tannin revealed that of the 48 plant samples screened, $34(70.83 \%)$ of them contained tannins while $14(29.17 \%)$ of the plants do not contain tannins. The result showed that tannins have been identified to be the most abundant chemical composition extraction from the 48 plant species used in making chewing stick. Presence of tannins in the ethanol, hexane and dichloromethane extracts have also shown to be absolutely correlated as the different extract revealed the same presence of tannins in specific plant. This might be due to the fairly high polarity of the various solvents used as extractants.

The folk-medicinal value and chemical composition of the plant species identified were also itemized below:

Table 2: Folk-Medicinal Values of selected plants

\begin{tabular}{|l|l|l|}
\hline S/No & Botanical Name & Folk-Medicinal Value \\
\hline 1 & Alchornea cordifolia & Healing of Teeth ache and mouth \\
\hline 2 & Alchornea laxiflora & Posses antimicrobial gents \\
\hline 3 & Alstonia boonei & Curing of fever, asthma, rheumatic pains, dizziness \\
\hline 4 & Anacardium occidentale & Curing of tooth ache, sore gums and cough \\
\hline 5 & Anogeissus leiocarpus & Used for oral hygiene \\
\hline 6 & Azadirachta India & Teeth and gum maintenance and cure of fever \\
\hline 7 & Blighia sapida & Curing of mouth wounds \\
\hline 8 & Bridelia ferruginea & Healing of mouth wounds \\
\hline 9 & Bridelia micrantha & Curing of headache \\
\hline 10 & Buchholzia coriacea & Used as anti-fungal and \\
\hline 11 & Calliandra portoricensus & Curing of headache, gonorrhea, lumbago, and pain \\
\hline 12 & Capsicum annuum & Curing of fever, cold and dysentery, act as stimulant \\
\hline 13 & Carpotobia lutea & Curing of stomach ache and used for oral hygiene \\
\hline 14 & Citrus aurantifollia & Used for oral hygiene \\
\hline 15 & Clerodondron buchholziii & Curing of fever \\
\hline 16 & Combretum racemosum & Curing of fever and cough \\
\hline 17 & Croton zambesicus & Curing of malaria \\
\hline 18 & Cynometra vogellii & Used for oral hygiene \\
\hline 19 & Diospyros monbuttensis & Used as anti-fungal and anti-bacteria agents \\
\hline 20 & Duranta erecta & Used for oral hygiene \\
\hline & &
\end{tabular}




\begin{tabular}{|c|c|c|}
\hline S/No & Botanical Name & Folk-Medicinal Value \\
\hline 21 & Garcinia kola & Curing of cough, tooth ache, fever and diabetes \\
\hline 22 & Garcinia mannii & Curing of cough \\
\hline 23 & Gliricidia sepium & Clearing microbes in mouth \\
\hline 24 & Glyphaea brevis & Curing of fever \\
\hline 25 & Hibsicusrosa-sinensis & Curing of cough \\
\hline 26 & Harungana madagascariensis & $\begin{array}{l}\text { Curing of fever, cough, dysentery, asthma, jaundice, diahhoea, } \\
\text { sore throat }\end{array}$ \\
\hline 27 & Jatropha curcas & Curing of gum bleeding \\
\hline 28 & Jatropha gossypiifolia & Healing of mouth cancer \\
\hline 29 & Jatropha multifida & Healing of mouth wounds \\
\hline 30 & Mallotus oppositifolius & Healing of mouth cancer \\
\hline 31 & Magnifera indica & Curing of malaria and sore gum \\
\hline 32 & Masscularia acuminate & Used for oral hygiene, curing of cough and lumbago \\
\hline 33 & Milletia thonningii & Curing of fever and sore throat \\
\hline 34 & Ocimum gratissimum & Curing of cough, cold, fever, chest pain, diarrhea \\
\hline 35 & Olax subscorpoidea & Curing of tooth ache \\
\hline 36 & Prersea gratissima & Curing of hypertension \\
\hline 37 & Phaulopsis imbracata & Used for mouth hygiene \\
\hline 38 & Psidium guajava & Curing of stomach ache and cough \\
\hline 39 & Pycnanthus angolensis & Clearing of 'white tongue' \\
\hline 40 & Sarcocephalus latifolius & Curing of malaria fever \\
\hline 41 & Senna siamea & Curing of fever \\
\hline 42 & Sida acute & Used for oral hygiene \\
\hline 43 & Sida corymbosa & Used for oral hygiene \\
\hline 44 & Terminalia schimperiana & Curing of sickle cell anemia \\
\hline 45 & Theobroma cacao & Acts as stimulant \\
\hline 46 & Trema orientals & $\begin{array}{l}\text { Provides remedy for fever, black tongue, cough, bronchitis, } \\
\text { dysentery }\end{array}$ \\
\hline 47 & Vernonia amygdalina & Curing of cough, diabetes \\
\hline 48 & Zanthoxylum xanthoxyloides & Curing of tooth ache and sickle cell anemia \\
\hline
\end{tabular}

\section{Discussion, Conclusion and Recommendation}

The long and variable history of the use of plants to improve dental health and promote oral hygiene has been known since antiquity. Cutting of roots tem or twings of tree and shrub have been used severally as traditional tooth brush commonly called chewing sticks. The use medical plants is an importance pant of traditional medicine in many culture and is the basis of ongoing efforts to develop new drugs in conventional medicine. Tannins have been reported to have anti-microbial properties especially around the mouth region. From the folk-medicinal values itemized in table 2, it has been revealed that the plant samples used for this research not only contain tannins but also other chemical compounds that could be useful to improving oral health or well being in general.

The result showed that tannins bas been identified to be the most abundance chemical ton extractors from the 48 plant species used in making showing stick.In conclusion, the results showed that most of the Nigerian chewing sticks do contain tannins which have antibacterial activities which may contribute to the reported anticaries effect of chewing sticks. These sticks may be sources for new lead antibacterial agents for therapeutic or preventive applications. Based on the result obtained, it was recommended that users of chewing sticks should be sensitized on the type of chewing sticks that are of potential therapeutic benefit (anti-microbial) to the mouth health especially those containing tannins.

\section{References}

Adekunle, A.A. and Odunkoya, K.A. (2006). Antifungal activities of ethanol and aqeous crude extrats of four Nigerian chewing sticks. Ethnobotanical leaflets http/www.stu/-eb/leaflets.

Ahmed, M., P. Khirtova and G. Icho, (2005). Comparative study of tannins of Acacia Nilotica and indigenous tannins materials in sudan with acacia mearnsiisuranaree, J.SCI.Technol, 12:259-265.

Akande TA and Ajao AT, 2011. Chemotherapeutic values of four Nigerian chewing sticks on bacterial isolates of dental infection. Global Journal of Science Frontier Research 11(8): 91-95

Akande, J.A. and Hayashai, Y. (2008). Potency extract constants from selected tropical sticks against staphylococcus areus and Etaphylococcusauricularis wordJournal of Microbiology and Bacteriology 
G.ill, L.S. (1992). Ethnomedicinal uses of plants in nigeriauniben press, bennin city, Nigeria, pp.279.

Hann, D.H, L. W. Rooney and C.F. Earp (1984). Tannins and phenols of sorgunCer. foods world 29:776-779

Homer KA, Manji F, Beighton D, 1990. Inhibition of protease activities of periondontopathic bacteria by extracts of plants used in Kenya as chewing sticks (mswaki). Archives of Oral Biology 35: 421-424.

Isawumi, M.A. (1978). Nigerian chewing sticks. Nigeria field43(4): 61-170

Isawumi, M.A. (1978a). Nigeria chewing sticks. Nigeria field43 (2) 50-58.

Isawumi, M.A. (1978b). Nigeria chewing sticks. Nigeria field43(3): 111-121.

Isawumi, M.A. (1979). Nigeria chewing sticks. Nigeria field44(4): 21-28

Kayode, J. (2005). Ethnobotanical survey and conservation of medicinal composite species in Benin Kigdome, Nigeria composite new letter $42.48-45$.

KemboiDoglas (2016). Ethnobotanical Medicinal Plants Used as Chewing Sticks among the Kenyan Communities. British Journal of Pharmaceutical Research 13(1): 1-8, 2016, Article no.BJPR.28833 ISSN: 2231-2919, NLM ID: 101631759

Odebiyi, O.O. and A, Sofowora (20009). Antimicrobial alkaloids from Nigeria chewing sticks. Planta med, 36:204-204

Odukoya, O.A., A.E. Thomas and A. Adepoju- Bello (2001). Tannic acid equivalent and cytotoxic activity of selected medicinal plants. West Afr. J. pharm. 15:43-45.

Price, M.L. and L.G. Butter (2017). Rapid visual estimation and spectrophotometer determinations of tannins content of sorghum. J. Agric. Food Chem., 25-1268 - 1273.

Sofowora A, 2008. Medicinal plants and traditional medicine in Africa. Spectrum Book Ltd., Ibadan, Nigeria. p. 289.

Sofowora, A. (2003). Medicinal plants and traditional medicine if Africa. Spectrum Books, Ibadan Nigeria

World Health Organization (WHO). The World Health Report, 2004, Geneva; 2004. 